\title{
From the Fall of Rome to Charlemagne (c.400-80o)
}

\author{
Alessia Rovelli
}

More than a century ago, in his stimulating reflections on the history of numismatic research, Ernest Babelon highlighted the seminal contribution of the 14th-century Italian humanist Francesco Petrarch. Immortalized for having inaugurated the critical study of classical literature, Petrarch was also the first to begin systematically acquiring and classifying the ancient coins gathered by peasants in the Roman countryside. As Petrarch himself explained in several letters, his aim was to decipher the coins' legends in order to compare them with other epigraphic texts - thereby establishing the foundations of numismatics as a historical discipline. ${ }^{1}$ For the 14 th-century humanist, the imperial portraits and the reverse types offered early answers, just as they also provoked further questions. The labours and insights of generations of subsequent scholars are amply displayed in the abundance of syntheses, catalogues, and corpora published over the course of the 2oth century, among which those dedicated to late imperial, Byzantine, and early medieval coinage rank among the finest.

Three decades have now passed since the appearance of the first volume in the Medieval European Coinage series, covering the coinage of early medieval Western Europe. ${ }^{2}$ Like the series as a whole, the first volume was largely conceived by the great historian and numismatist Philip Grierson. Notwithstanding recent advances in scholarship, the volume remains of fundamental importance, both for its lucid discussion of the historical and numismatic context and for its catalogue of the collection of the Fitzwilliam Museum, which offers a synoptic vision of the principal post-Roman issues from the $5^{\text {th }}$ to the 10 th centuries. A decade later, John Kent's volume on the $5^{\text {th }}$ century concluded the corpus of imperial Roman issues (The Roman Imperial Coinage) launched by Harold Mattingly and E.A. Sydenham in $1923 .{ }^{3}$ Similar achievements can be

1 Babelon, Traité des monnaies greques et romaines, vol. 1, p. 83; the first chapter (pp. 66-326) consists mainly of a history of the field of numismatics.

2 Grierson and Blackburn, Medieval European Coinage 1 (hereafter MEC 1).

3 Kent, The Roman Imperial Coinage X (hereafter RIC X). The same chronological span, which takes the issues of Anastasius I as the starting point for the Byzantine series, was adopted in Grierson and Mays, Catalogue. 
claimed for Byzantine coinage, which is crucial to the understanding of Western European issues. ${ }^{4}$

Even a cursory glance at these weighty tomes reveals the underlying method, which refuses to bracket off historical considerations from those which might ostensibly seem more specifically numismatic in nature. In this regard, the VIII Settimana di Studi held in Spoleto in 1960 by the Centro italiano di studi sull'alto Medioevo, which brought together historians and numismatists, represents a crucial turning point. ${ }^{5}$ As Cécile Morrisson observed, that gathering marked "le véritable départ de l'histoire monétaire européenne de l'Antiquité tardive et du haut Moyen Age". ${ }^{6}$ The lively "discussions" which (in keeping with the tradition of the Settimana) followed each of the lectures still merit careful reading for the challenges and topics they raised, and for the ways in which these might be addressed through the appropriate analysis of coins. Identifying the issuing authority (along with distinguishing imitations and forgeries), the chronology, the mints, the intrinsic values, and the volume of issues remain the necessary first steps. This stage of research is especially complex for many of the issues of the period under consideration here, which are often characterized by very corrupt types and legends. The challenge is especially acute for bronze issues. ${ }^{7}$

\section{The 5th Century: Late Roman Issues}

The coinages which developed in Europe over the course of the early Middle Ages have their roots in late Roman coinage: namely, the monetary system in use within the Roman Empire from the late 4th century A.D. through the end of the 5 th. ${ }^{8}$ This in turn derived from the Constantinian reforms, which substituted gold for silver as the basis of the imperial coinage. This significant change notwithstanding, it bears noting that throughout late antiquity the Roman monetary system maintained the trimetallic system as conceived under Augustus. ${ }^{9}$

4 Hendy, Studies in the Byzantine Monetary Economy; Morrisson, Byzance et sa monnaie (with references to earlier bibliography).

5 Moneta e scambi nell'alto Medioevo.

6 Morrisson, "Histoire monétaire et numismatique", p. 281.

7 Hohlfelder, "A sixth-century hoard from Kenchreai", p. 101; RIC X, pp. 31-33; Grierson and Mays, Catalogue, p. 239; and Hahn, Money of the Incipient Byzantine Empire, p. 13.

8 MEC 1, pp. 1-16; and Hendy, The Economy, Fiscal Administration and Coinage of Byzantium, no. 7 .

9 The following synthesis of late Roman coinage is based largely on the texts cited in $\mathrm{nn}$. 2, 3 , and 4 . 

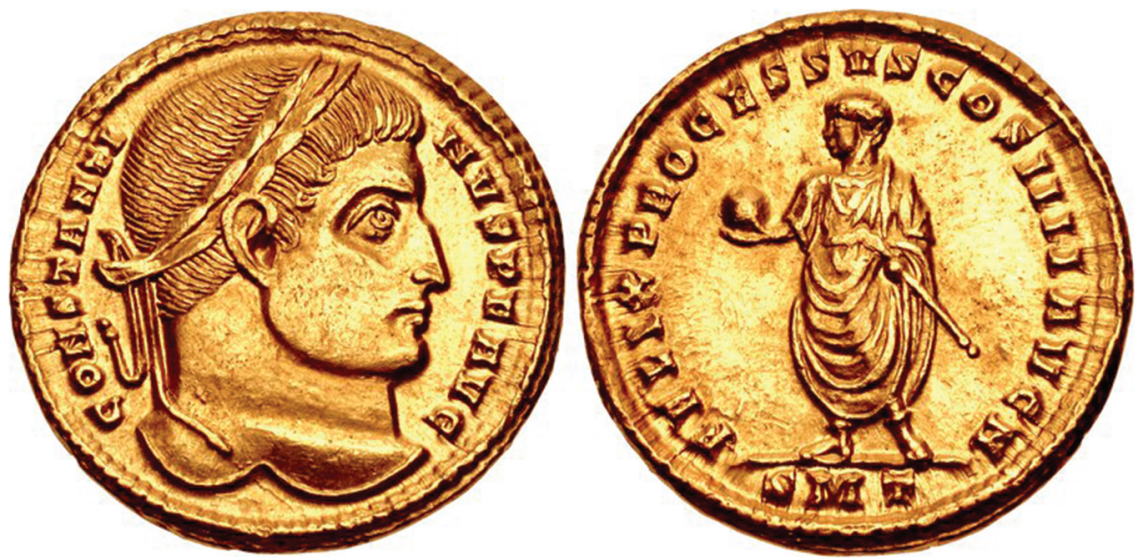

FIGURE 4.1 Constantine I (306-337), gold solidus, Ticinum mint. SOURCE: CNG.

The basis of the new late Roman system was the solidus, a coin weighing (in Roman terms) 24 carats/siliquae, equivalent to $1 / 72$ of the Roman pound (4.54 grams) (Figure 4.1). This new coin was probably introduced in 309 in the mint at Trier, which was then the most important of the mints controlled by Constantine, who had established his residence in the city. It was progressively struck by the other imperial mints, replacing the heavier Diocletian aurei (weighing $1 / 6 \mathrm{olb}=5.46$ grams).

Multiples of the solidus (the so-called "medallions") were also issued on occasion, but these are generally taken to have been celebratory issues and did not form an integral part of the monetary system. The heaviest known specimen is the 12-solidus medallion struck in the name of Libius Severus, weighing 53.62 grams. ${ }^{10}$ Most specimens have been discovered beyond the frontiers of the empire, indicating not only their appeal among the Germanic tribes, but also their use as tribute payments alongside gold and silver coins.

Other gold issues included the semissis ( $1 / 144 \mathrm{lb}$, therefore a half-solidus), which was similarly an essentially ceremonial coinage distributed as donativa; and the tremissis (1/216 lb, c. 1.5 grams), likely introduced in 383 . Within the Romano-Barbarian series, the tremissis (or triens), the smallest of the gold denominations, enjoyed the broadest diffusion, while the solidus remained the principal denomination of the Byzantine monetary system. In Western Europe, however, the solidus did not entirely disappear; it survived mainly as a unit of account, no longer represented by a physical coin. In the systems that 
continued to be based on gold, it was worth three tremisses, while in the silverbased Carolingian system it was worth 12 denarii, as we will see.

Although silver continued to be coined, it no longer enjoyed the importance it had maintained under the Principate, instead playing a secondary role compared to gold. The most widely used silver denomination, especially towards the late 4th century, was the so-called siliqua. These coins owe their names to the mistaken assumption among earlier numismatists that they had the value of one gold siliqua (1/24 of the solidus) as a money of account. In fact, the siliqua (carat/ keration in Greek) was a fraction of a Roman pound $(1 / 1728=0.19$ grams). At the moment of its introduction, probably in 358 , the silver siliqua weighed roughly 2 grams (1/156 lb according to some scholars, $1 / 144$ according to others), but we find considerable variation, likely due to the flexible metal ratios. ${ }^{11}$ Some specimens dating to the end of the 4 th century would seem to have been struck at 1 / $288 \mathrm{lb}$ (1.13 grams). We also find fractions (e.g., half-siliquae, particularly common in the West) as well as larger denominations of varying weights; like gold, these latter were originally struck in two different denominations: heavy and light miliarenses, weighing respectively $1 / 60$ and $1 / 72 \mathrm{lb}$.

The circumscribed volume of silver issues should not lead us to imagine a dearth of this metal. In late antiquity, silver circulated above all in unmonetized forms, whether in ingots (with weights often equivalent to fractions or multiples of the pound) or as objects (and fragments thereof), often found together with coins in hoards, sometimes in significant quantities. ${ }^{12}$

The third branch of the monetary system consisted of an articulated series of bronze issues. The identification of the bronze denominations mentioned in written sources raises problems analogous to those that we encounter with silver issues; as a result, these are generally referred to on the basis of their diameter, namely, $\mathrm{AE} 1, \mathrm{AE} 2, \mathrm{AE} 3, \mathrm{AE} 4$. This last had a diameter around $14 \mathrm{~mm}$ and a weight of roughly 1.4 grams. Over the course of the second half of the 4th century and the first decades of the $5^{\text {th }}$, the coining of larger denominations was gradually abandoned. In the second half of the $5^{\text {th }}$ century, the AE 4 (often referred to as the nummus) remained the only bronze denomination struck by the imperial mints. During this period the AE 4 underwent various

11 For an echo of these aspects, with particular attention to the ratio AV:AE, see the anonymous treatise De rebus bellicis (English edition and commentary in Ireland, De rebus bellicis).

12 Baratte, "Les ateliers d'argenterie au Bas-Empire"; $M E C$ 1, pp. 96-97; Delmaire, Largesses sacrées et res privata, pp. 471-94; Baratte, "Les objets précieux"; Johns, The Hoxne Late Roman Treasure. See also a volume on the Traprain Law hoard: Hunter and Painter, Late Roman Silver. 
changes in weight, which are especially evident if we compare the Eastern issues (which saw their weight fall to 0.20 grams during the reign of Zeno) with the Western ones (which suffered a less marked drop, maintaining a theoretical weight close to 1 gram). The dimensions of the $\mathrm{AE} 4$ likewise diminished during this period, with most specimens under $10 \mathrm{~mm}$. Together, the reduced weight and diameter justify the common practice of referring to these coins as minimi (Figure 4.2). ${ }^{13}$

The imperial monetary system of the $5^{\text {th }}$ century therefore appears much simplified in comparison to earlier periods. The reduction in denominations was accompanied by the gradual closing of the mints that were still mentioned in the Notitia Dignitatum (c.40o): for the West, Siscia, Aquileia, Rome, Lyon, Arles, and Trier were the sites of the moneta publica, responsible for the issuing of bronze coinage; the coining of precious metals, in turn, took place principally at Sirmium, Milan, and Ravenna. ${ }^{14}$ This decline likewise figures among the consequences of the loss of the western provinces, Britain above all. Gaul offers a clear example: Arles remained the only active mint through to $475^{-476}$, and even there the activity was discontinuous. Rare solidi in the name of Romulus Augustulus can in fact be attributed to Arles, but the bronze issues stopped with the $\mathrm{AE} 4$ in the name of Johannes (423-425), while silver issues ceased even earlier - the last siliquae are those issued in 418 in the name of Honorius. Trier had minted significant volumes of coins in all three metals during the 4th century, but it halted bronze issues in 395 and thereafter was only sporadically active. Lyon, the oldest mint of Roman Gaul, ceased its activity following a series of gold and silver issues in the names of Constantine III and Jovinus (both usurpers) issued between 407 and 413. Under the Burgundian king Gundobad, Lyon would once again mint silver and bronze (and perhaps gold), but by then the political and institutional context was dramatically transformed. ${ }^{15}$

In Italy, as might be expected, the developments followed different rhythms, but the overall trends were essentially the same. In the second half of the $5^{\text {th }}$ century, the moneta publica at Rome was the only imperial mint in the West still producing bronze coins.

Notwithstanding the changes described here, and even in its simplified form, the late Roman monetary system remained an articulated system with at least one denomination for each of the three metals being coined. It likewise remained multifunctional, sufficiently flexible to accommodate both

\footnotetext{
13 Morrisson, "Nummi byzantins et barbares du VI siècle", p. 187.

14 Hendy, The Economy, Fiscal Administration and Coinage of Byzantium, nos. 4, 5, 6; Delmaire, Largesses sacrées, pp. 495-528.

15 Brenot, "Du monnayage imperial au monnayage mérovingien".
} 

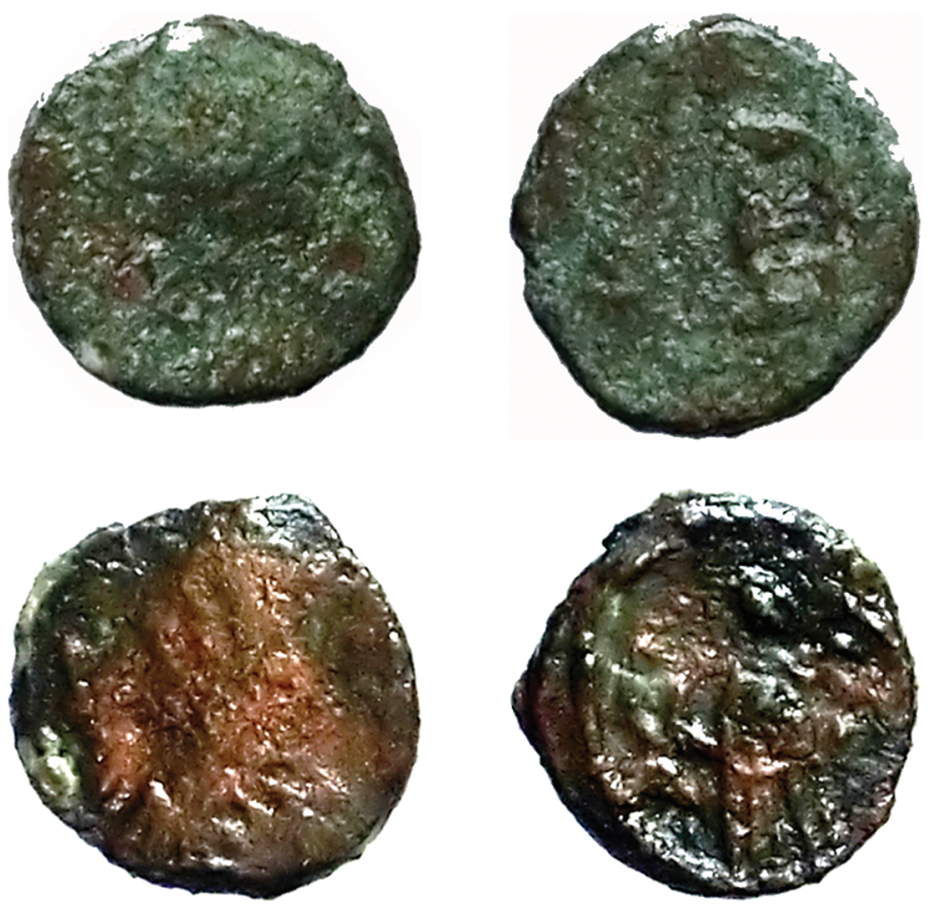

FIGURE 4.2 5th/6th-century minimi from the Basilica Hilariana (Rome).

Rovelli, "Aspetti della circolazione monetaria", pp. 209-10, nos. 174

(o.55G, 3.20mm Diameter), 179 (o.53G, 3.20mm Diameter) Source: author's photographs.

significant payments and quotidian transactions ${ }^{16}$ in the context of an economic and monetary framework in which not only the state (through its fiscal structures, the annona, and the provisioning of the military $)^{17}$ but also the market provided an engine for continuing monetary circulation. ${ }^{18}$

16 This salient feature of Roman monetization was underscored by Michael Crawford, notwithstanding his essentially "primitivist" interpretation of the Roman economy and of the role of coinage: Crawford, "Money and exchange in the Roman world", p. 41. On the debate inspired by this article, see Howgego, "Why did ancient states strike coins?".

17 See the survey in Reden, "Money in the ancient economy". For an early medieval perspective, Wickham, "The other transition"; Wickham, Framing the Early Middle Ages, pp. 56150; Hendy, "East and west"; and the bibliography noted above, nn. 8, 12.

18 Different approaches are given in Kajava (ed.), Gunnar Mickwitz nella storiografia europea tra la due guerre; Carrié, "Les échanges commerciaux et l'État antique tardif”; Carrié, "Were late Roman and Byzantine economies market economies?"; and Banaji, Exploring the Economy of Late Antiquity. 


\section{$5^{\text {th }}$ to $7_{\text {th }}$ Centuries: The Fragmentation of the Monetary Systems}

As in so many other respects, the $5^{\text {th }}$ century was a turning point for the monetary system: although the persistence of its overall structures ensured that it remained deeply connected to its Roman heritage, it was also expressive of the transformations underway. To put this in focus we must briefly broaden our horizons. If the discussion so far has focused on Roman coinage and the state structures that it reflected, it is now necessary to survey the geographical, political, and economic shifts which gradually led northwestern Europe to reorient itself around the Carolingian Empire and its coin: the silver penny. ${ }^{19}$ The Mediterranean South witnessed a different shift, thanks to the persistence of its Romano-Byzantine heritage and to the Arab conquest of Spain (705-711). In Spain, the introduction of a new system - that of the dinar and its fractions (similar to what was then current in north Africa) - kept the Iberian peninsula anchored to gold, as it had been under the Visigoths, rather than silver. ${ }^{20}$

Within this framework, Italy - first Byzantine and then Lombard - served as a sort of bridge between the different monetary systems. At the end of the 8th century, Charlemagne's conquest of the Lombard kingdom pulled north central Italy into the Frankish monetary zone. But it bears mentioning that the introduction of the Carolingian silver-based system (in which silver denarii replaced the gold tremisses of the Lombards) was the result of a military defeat and not, as in Gaul, the endpoint of a coherent political and monetary process. It is not by chance that the duchy of Benevento, in which Carolingian power was more nominal than effective, remained largely anchored to the Byzantine solidus throughout this period. The silver pennies struck in the mints of Benevento and Salerno never achieved the volumes attested for the local solidi and tremisses. ${ }^{21}$

The early medieval monetary fragmentation is unsurprising if we consider that in the Greco-Roman juridical tradition, coinage found within the state is its own raison dêtre. If we observe the diversity that characterized the individual Roman provinces, even within their shared imperial structure, ${ }^{22}$ one can easily appreciate the difficulty of generalizing about not just early medieval

19 Spufford, Money and Its Use in Medieval Europe, pp. 1-54; Bompaire, "Du solidus d'or au denier d'argent"; Devroey, Économie rurale et société dans l'Europe franque, pp. 158-69; Bruand, Voyageurs et marchandises au temps carolingiens, pp. 155-84; and Naismith, Medieval European Coinage 8.

Sénac and Gasc (eds.), Monnaies du haut Moyen Âge; Castro Priego, "Absent coinage"; and Doménech Belda, "Moneda y espacios de poder en el reino visigodo".

21 Arslan, "Sequenze dei conii"; and Rovelli, Coinage and Coin Use in Medieval Italy, no. Xvi.

22 Wickham, Framing, p. 3. 
society, but also the monetary systems that emerged from a common Roman matrix. A wide array of variables led to an initial distinction between those societies marked by statelike structures, such as Italy, Gaul, Spain, England (to an extent, though it struck no coinage for over two centuries), ${ }^{23}$ and those societies organized predominantly along tribal lines, or Barbaricum, as it is called in contemporary sources (e.g., the areas of Germany furthest from the Rhenish and Danubian limes, Scotland, Ireland, and the Baltic and Black Sea regions).$^{24}$ Each of these two broad groups could be further subdivided, given that each province had not only developed its own particular expressions of Romanization, but had also undergone accordingly different processes of ethnogenesis. ${ }^{25}$

In seeking to understand the making of the new economic systems and political entities, there is much to be learned from first understanding the patterns of use and diverse reasons for non-use of coined money, ${ }^{26}$ the commercial ${ }^{27}$ and other ${ }^{28}$ pathways of coin diffusion, and the chronology of the adoption of monetary instruments (occasionally through the initial production of paramonetary objects, such as the so-called bracteates, whose function was predominantly ornamental or apotropaic). ${ }^{29}$ It is interesting to note that provisions regarding money often featured among the first legislative acts of new sovereigns, even in the absence of a clear royal monopoly over coin issues.

23 On the resumption of coin production in Britain, see Abdy, "After Patching"; and Williams, "The Circulation and function of coinage in conversion-period England".

24 Le Jan, La société du haut Moyen Âge, pp. 30-54.

25 Halsall, Barbarian Migration and the Roman West; Pohl and Mehofer, Archaeology of Identity; and Mathisen and Shanzer, Romans, Barbarians and the Transformation of the Roman World.

26 Naismith, "The social significance of monetization in the early Middle Ages"; and Bougard, "Le credit dans l'Occident du haut Moyen Âge".

27 McCormick, Origins of the European Economy, pp. 681-88; Blackburn, "'Productive' sites and the pattern of coin loss in England"; Morrisson, "Emporia, money and exchanges"; Naylor, "Coinage, trade and the origins of the English emporia"; Skre, "Markets, towns and currencies"; and Skre, Means of Exchange.

28 Grierson, "Commerce in the Dark Ages". The originality of Philip Grierson's approach toward the "gift economy" is highlighted in Devroey, Économie rurale, pp. ${ }^{175^{-7}}{ }^{8}$ and n. 74. For more recent contributions to this vast theme, see Laiou, "Economic and noneconomic exchange"; Feller, Gramain, and Weber, La fortune de Karol; Curta, "Merovingian and Carolingian gift giving"; Davies and Fouracre (eds.), The Languages of Gift in the Early Middle Ages; Morrisson, "La monnaie byzantine hors de l'Empire"; and Feller and Rodriguez (eds.), Objets sous contrainte.

29 Werner, Münzdatierte Austrasische Grabfunde laid out the fundamentals of the problem; Magnus, Roman Gold and the Development of the Early Germanic Kingdoms. 
This was the case, for instance, in the so-called Lex Gombetta (after Gundobad of Burgundy), which regulated the circulation of solidi. ${ }^{30}$

Although an exhaustive study of these processes is beyond the scope of this chapter, let us examine a few instances more carefully, starting with the Ostrogothic coinage, the most structured of all those which emerged in the postRoman West. For our purposes, the Ostrogothic monetary system exemplifies two different themes: coinage as a means of legitimizing power ${ }^{31}$ and coinage as both a fiscal tool and a means of exchange. ${ }^{32}$ The Ostrogothic sovereigns made sophisticated choices in each, wielding gold, silver, and bronze issues to achieve a specific political objective.

It is well known that the issue of gold coinage (and of solidi in particular) was a prerogative reserved for the emperor. This perhaps explains why the Ostrogoths, who ruled Italy by a mandate from Zeno (who had named Theodoric patrician and general), not only avoided contesting this principle, but actively struck gold coins that faithfully reproduced the types, alloys, and weights of their imperial counterparts. Indeed, the Ostrogothic gold issues bear the name of the emperor, with the sole modification being the monogram of Theodoric that appears on some solidi at the end of the reverse legend. Moreover, it seems likely that the personnel of the Ostrogothic mints at Rome, Ravenna, Milan, Ticinum/Pavia, and Sirmium - all of which had been active during the preceding imperial period - were also Roman. Under the Goths, Ravenna and Rome remained the principal mints, and they preserved at least in principle the distinction between the palatine mint (Ravenna) and the moneta publica (Rome). ${ }^{33}$

Quite different, and original, were the iconographic choices adopted for the silver and bronze coinage. Following the capture of Ravenna in 493, Theodoric had his soldiers elect him king with a formula signifying "king in Italy". The double-nature of his titles - as both king and Roman functionary - and the dualistic structure of his kingdom (in which Romans continued to occupy important roles in the civil administration) is reflected in the silver issues. For the so-called siliqua fractions, the obverse continued to be reserved for the emperor; on the reverse, however, and therefore in a subordinate position, appeared the monogram or the name of the Ostrogothic king, that is, the ruler

$30 \quad M E C$ 1, p. 5; and Lafaurie and Pilet-Lemière, Monnaies du haut Moyen Âge découvertes en France, p. 19.

31 Arslan, "Dalla classicità al Medioevo"; and Asolati, Praestantia nummorum, pp. 53-111.

32 Vera, "Dalla liturgia al contratto"; Vera, "Stato, fisco"; and Rovelli, "Contextes urbains vs ruraux", pp. 149-52.

33 Metlich, The Coinage of Ostrogothic Italy, is the most recent corpus of Ostrogothic coinage at this writing. 

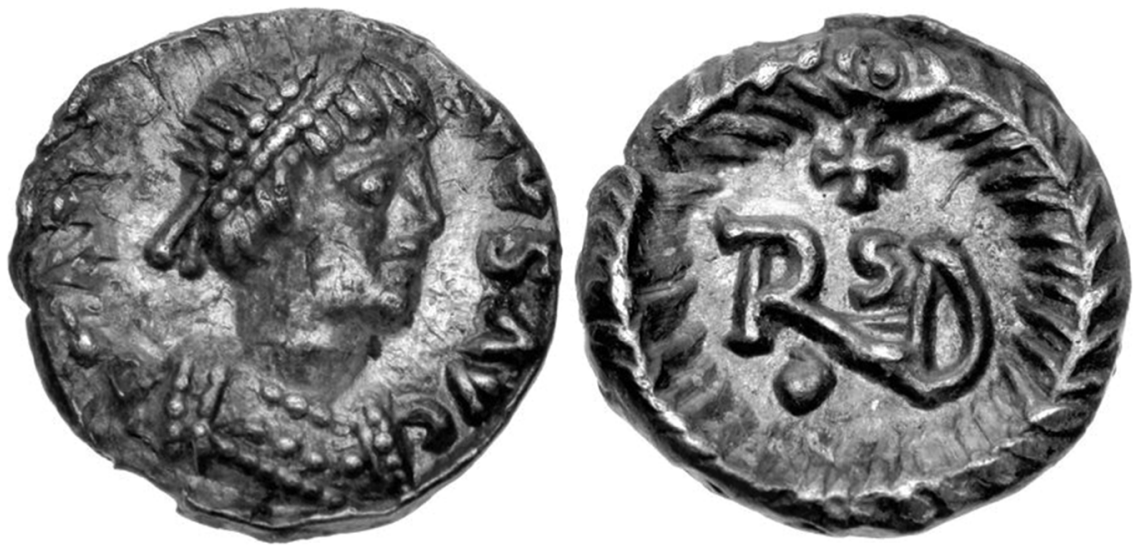

FIGURE 4.3 Theodoric (493-526), silver quarter-siliqua.

SOURCE: CNG.

of the delegated authority (Figure 4.3). These coins would enjoy broad circulation north of the Alps, an initial push having been given by the Ostrogothic expansion into Provence. Their role, not only political but also economic, is underscored by the fact that the Byzantines continued to issue siliqua fractions after reconquering Italy, even though this denomination was struck in neither Constantinople nor any of the other eastern mints. ${ }^{34}$ Even the so-called minuti argentei of the early Merovingian period, to be discussed below, can be considered heirs or imitators of these issues.

Yet another argument can be made for the bronze issues, whose circulation was mainly local but which had the capacity to reach a vast public - Roman and Gothic alike - through their use in everyday exchanges. The choice of types, which evoked national sentiments for each people, summarizes neatly Theodoric's political programme. The wolf with twins which appears on the folles, for example, dated variously to the late $5^{\text {th }}$ and early 6 th centuries, obviously descended from a venerable tradition in Roman coinage, even though the type itself had not been struck since the Constantinian era. Its return two centuries later therefore signified the deliberate recovery of an evocative iconography for the Romans, as well as an embrace of the Germanic imaginary in which wolves figured prominently. Moreover, it is precisely in the bronze issues that the royal claims of the Ostrogoths affirmed themselves most explicitly, and on occasion most spectacularly: consider the folles of Theodahad which feature on the obverse a bust of the king wearing the Spangenkappe, the Germanic symbol of power; and on the

34 Brenot, "Du monnayage impérial au monnayage mérovingien”; Callegher, “Tra Bizantini e Longobardi in Friuli", pp. 673-79; and Morrisson, "Le zecche nell'Italia bizantina", p. 417. 

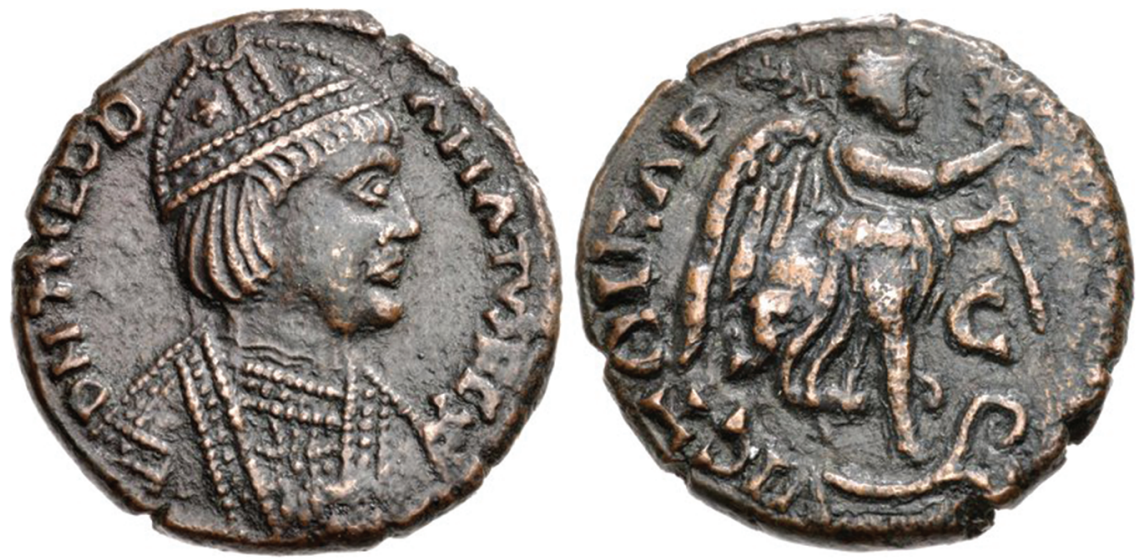

FIGURE 4.4 Bronze follis of King Theodahad (534-536). SOURCE: CNG.

reverse the equally evocative depiction of Victory on the prow of a ship, with SC (senatus consulto) in the field and the legend victoria principum (Figure 4.4).

It is worth noting that even the kingdom's final issues upheld the original iconographic choices, notwithstanding the onset of Byzantine aggression. Even as defeat loomed, the Ostrogothic gold issues continued to respect the imperial monopoly on gold aurei, though they abandoned the types bearing the name of Justinian in favour of those bearing the name of Anastasius, who in 497 had legitimated Ostrogothic power in Italy.

Innovation, but also a return to "classical" Roman models, also characterizes the bronze issues insofar as the denominations themselves are concerned. At

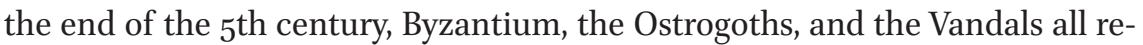
sumed coining multiples of the nummus. The origins of this innovation, which some scholars attribute to the Vandals and others to the Ostrogoths, remain controversial and will not be discussed here. ${ }^{35}$ What is crucial, however, is the new importance accorded to bronze. Even if the return to a multidenominational bronze coinage in the West lasted only briefly, the phenomenon reflects continuing demand for petty coinage, especially in the Mediterranean region, as is also well-demonstrated by the persistent circulation of late Roman bronzes and the sizeable production of minimi (frequently illegible, but probably often dateable to the 6th century). In Africa between $c .450$ and 533 , the Vandals

35 Hendy, Studies in the Byzantine Monetary Economy, pp. 488-9o; MEC 1, pp. 21-22 and 3132; RIC X, pp. 218-19; Morrisson, "L'atelier de Carthage", p. 72; Metlich, Coinage, p. 47; Arslan,"Dalla classicità al Medioevo", p. 438; and Rovelli, "En marge de quelques émissions d'Odoacre et de Baduila", p. 44. 

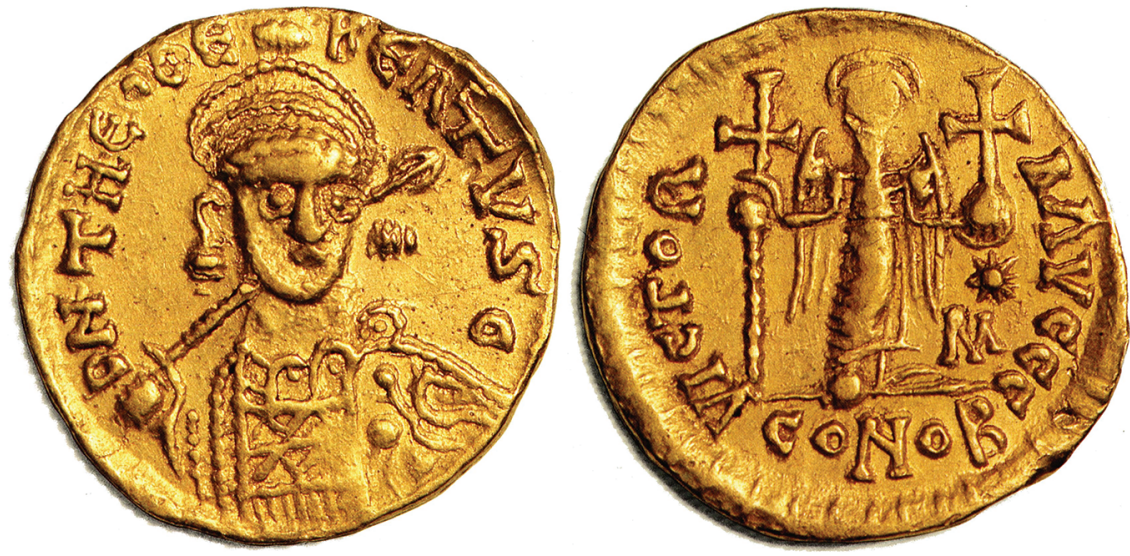

FIGURE 4.5 Gold solidus of King Theodebert (534-548).

SOURCE: WIKIPEDIA COMMONS.

issued both the nummus and multiples of 4, 12, 21, and 42 nummi. ${ }^{36}$ In Italy, the Ostrogothic system was articulated (like the Byzantine system designed by Anastasius) on a decimal base: a follis of 40 nummi; denominations of 20, 10, and 5 nummi; and minimi of uncertain value.

If the respect of the Gothic rulers for imperial prerogatives can be understood as a means of attesting the legitimacy of their own power in Italy, equally significant is the opposite choice, as evidenced in Gaul during roughly the same years, under the reign of Theodebert (534-548). The Frankish king, lacking imperially delegated authority, had entirely different aims: namely, to demonstrate the legitimacy of a power that had been independently acquired. Justly famous is the solidus that he issued in his own name, which did not fail to elicit the indignation of Procopius (The Gothic War, III.33.5-6), proof of the effect that the series had on contemporary observers (Figure 4.5). ${ }^{37}$ Theodebert's gesture remained for a time an isolated instance; from the late $5^{\text {th }}$ century through to the end of the 6th, the gold issues of the barbarian kingdoms limited themselves to imitating Byzantine imperial models.

The adoption of pseudo-imperial types also responded to the need to encourage circulation by choosing well-known and respected types, notwithstanding their gradual alteration. In Gaul and Spain, it was only toward 580 that imitations of imperial types were abandoned in favour of "national" types. The simultaneity of the shift might lead one to think of the parallel evolution of similar processes, but in reality the differences were significant. Consider, in

$36 \quad$ Morrisson, "L'atelier de Carthage".

$37 \quad M E C_{1}$, p. 5. 
regards to the Merovingian issues, the preeminent role assumed by the moneyers, whose name appears alongside that of the mint, whereas the king is mentioned only rarely. ${ }^{38}$ Conversely, in Visigothic Spain, it is the name of the king that dominates. In both cases, it can be difficult to define the nature of the issues (royal or otherwise) and the degree of control exercised by the authorities, and, as studies have shown, one cannot rely only on the legends. ${ }^{39}$

Lombard coinage offers a further example of the ways in which apparently similar developments might in fact follow quite distinct trajectories, dictated by local conditions. The Lombards also developed a "national" coinage roughly a century after settling definitively in a territory that had previously been under imperial control. (Their migration came to an end only in 568 when, having left Pannonia, they entered Italy through the eastern Alps.) The acquisition of national types, after an initial phase of pseudo-imperial issues, therefore likens the Lombard coinage to the Visigothic and Frankish experiences, but the outcome proved markedly different from either.

In the Lombard realm, the abandonment of Byzantine types occurred under Cunincpert (688-700), who launched a monetary reform in two phases. The first phase (688-692/3?) affected iconographic aspects and led to the replacement of the imperial bust with that of the Lombard king, the accompanying legend making him all the more easily identifiable. The name of the ruler (designated as rex) was repeated on the reverse..$^{40}$ It is interesting to observe that here, the abandonment of the imitation type in favour of a new iconography entrenched itself only after the peace accord of 68 o between the Lombards and the Byzantines, which legitimized Lombard sovereignty over much of Italy ${ }^{41}$ This delay is all the more striking if one considers that the Edict of Rothair, promulgated in 643, was the first instance in Germanic legislation to grant the king a monopoly over coinage. ${ }^{42}$ Even so, and although royal and ducal monograms had appeared on the silver issues from the very beginning, ${ }^{43}$ the visible expression of royal power on gold issues seems to have waited until after the treaty with the Byzantines.

The second phase of Cunincpert's monetary reform was similarly important, and, for our purposes, the most significant. To a further iconographic innovation was added a change in the intrinsic value of the tremisses. The reverse

38 MEC 1, pp. 97-102, 113-17; and Lafaurie and Pilet-Lemière, Monnaies du haut Moyen Âge, pp. $13-23$.

39 Martín Viso, "Circuits of power in a fragmented space"; and Chambon, "Lidentification des noms d'ateliers monétaires mérovingiens".

40 Arslan, "Una riforma monetaria di Cuniperto, re dei Longobardi".

41 On the importance of this agreement, see Delogu, Le origini del Medioevo, pp. 11-38.

42 Edictum Rothari, cap. 242.

43 On the attribution of the monograms, see Callegher, "Una moneta di re Arioaldo". 

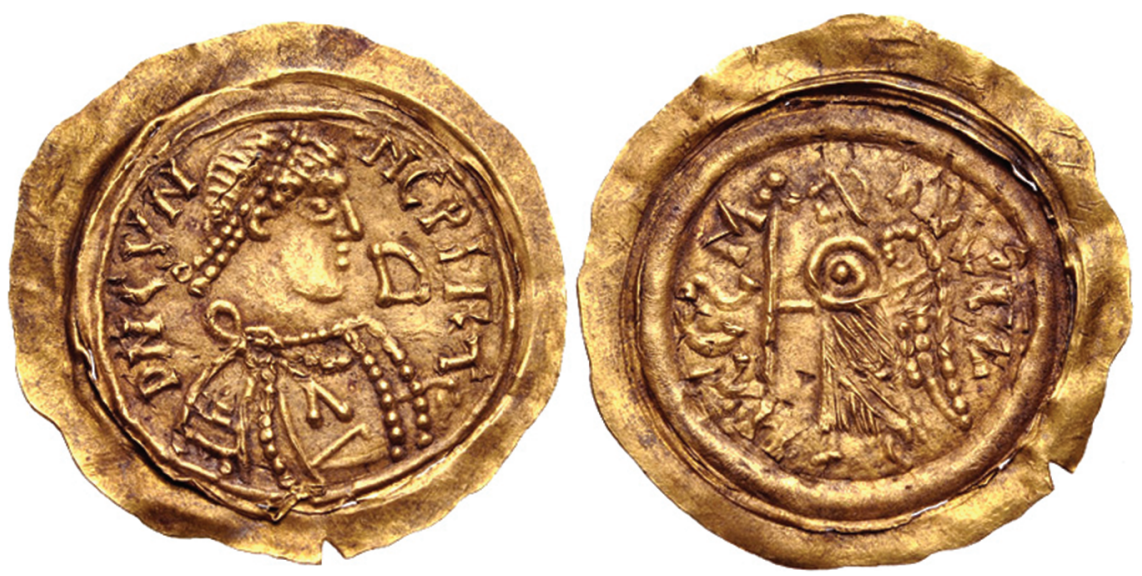

FIGURE 4.6 Gold tremissis of King Cunincpert (688-700). SOURCE: CNG.

was henceforth characterized by a winged Saint Michael (a reworking of the imperial Victoria), whose cult had already become a major element of national cohesion (Figure 4.6). As for the intrinsic value, Cunincpert decided to match the fineness of his tremisses to those issued in Constantinople and the Byzantine mints in Italy. The Lombard tremisses therefore reached an exceptionally high degree of fineness, between 94 and 99 per cent, with negligible oscillations between minimum and maximum values. ${ }^{4}$

The fineness of the Lombard issues remained high (92 to 93 per cent) through the reign of Aripert II (701-712). Cunincpert's monetary policy appears all the more original if one considers that in the very same years in which the Lombard tremissis was raised to an intrinsic value above go per cent, its Merovingian counterpart - whose fineness had already dropped below 20 per cent - disappeared altogether, to be replaced by the silver penny. It was only from the reign of Liutprand onward that the Lombard gold issues saw a drop in their fineness, in a process paralleling that of the Byzantine mints of Ravenna and Rome. ${ }^{45}$

One can wonder, however, about the real reasons behind the decline in the intrinsic value of Liutprand's tremisses, whose fineness ranged from 39 to 74 per cent. In searching for a possible answer, it is necessary to keep in mind the evidence concerning the volume of issues and its considerable increase, insofar as this can be reconstructed based on coin finds and the study of dies. Ermanno Arslan has estimated that a total of 15.14 dies were used under Cunincpert, as

44 Arslan, "Una riforma monetaria".

45 Rovelli, Coinage and Coin, nos. v, VI, XIV. 
compared to 293.28 for Liutprand. ${ }^{46}$ As regards Lombard coinage, the latter number is rivalled only by the Beneventan issues of Arechis II. ${ }^{47}$ If these statistics are set against the parallel decline of Byzantine issues in Italy, the interruption of Byzantine tribute payments to the Lombards after the peace of 68 o, and the probable impact of both on the Lombards' available gold reserves, the reduction in fineness of Liutprand's tremisses might instead be read in a "positive" sense, and from a totally different perspective than the Frankish decision to embrace silver. The reduction in the intrinsic value might have been an expedient to address the demand for coinage, assuring appropriate monetary production despite the decline in available gold supplies. ${ }^{48}$

The evidence presented here (however briefly) raises questions that go well beyond purely monetary concerns, suggesting that over the course of the 8th century Byzantium continued to be the principal political, monetary, and economic interlocutor of the Lombards. In this sense, as mentioned above, the introduction of the silver penny into Italy would seem to have been the monetary consequence of the Lombards' military defeat, rather than the natural embrace of silver monometallism that we find in northern Europe. We are therefore dealing here with a very different path than that taken in Merovingian Gaul around 68o, or in Frisia and England, where the adoption of silver issues, the so-called sceattas, followed in the wake of renewed trade contacts. ${ }^{49}$

\section{7th to 8th Centuries: From Gold to Silver}

To identify the stages that marked the passage from gold to silver, it is helpful to look in greater detail at the issues from Merovingian Gaul. Indeed, it is through these issues - which span nearly 250 years - that one can trace a theme that has continued to inspire historiographical debates since Henri Pirenne proposed his famous thesis. ${ }^{50}$

Merovingian coinage is traditionally seen as undergoing three distinct phases. ${ }^{51}$ The first, already touched on above $(c .500-587$ ?), was characterized

\footnotetext{
46 Arslan, "La monetazione di Ratchis, re dei Longobardi".

47 Arslan, "Sequenze dei conii".

48 Delogu, Le origini del Medioevo, pp. 84-85; and Rovelli, "La moneta al tempo di Desiderio".

49 On coin circulation and monetary reforms in northern Europe, see Naismith, "Kings, crisis and coinage reforms in the mid-eighth century"; and Naismith, "Social significance". See also $n .55$ below.

50 Delogu, "Reading Pirenne again".

51 The following synthesis is based mainly on $M E C$ 1, pp. 81-154; Bompaire, "Du solidus d'or au denier d'argent”; and Lafaurie and Pilet-Lemière, Monnaies du Haut Moyen-Âge, pp. 9-31.
} 
by imitative solidi and tremisses. One finds the names of the emperors Anastasius I (491-518), Justin I (518-527), Justinian I (527-565), and Justin II (565578). In Provincia/Provence, which remained under Ostrogothic control until 536 , issues in the name of the Eastern emperors continued through to the beginning of the 7 th century, as demonstrated by imitations of the Heraclius-type datable to $610-613$. These series occasionally bear monograms with the name of the king, though strikingly there is no known specimen with a monogram that can be plausibly associated with Clovis. ${ }^{52}$ Some monograms have enabled Burgundian issues to be distinguished, while archaeological finds have led to the identification of Visigothic tremisses minted in Septimania.

Alongside the gold issues, we also find the production of bronze nummi and lightweight silver fractions, the so-called minuti argentei. Among the latter, it seems possible to distinguish two different denominations, one theoretically weighing 1 siliqua (o.188 grams) and the other 2 siliquae (o.377 grams). Until recently, these were assumed to have been produced above all in Provence, probably at Marseille. Based on archaeological findings, however, it is now possible to imagine a more sustained production over the course of the 6th century, in an area that also included much of the Rhineland-Moselle region, particularly around Worms, Strasbourg, and Metz (which would become the capital of Austrasia). Some specimens, probably issued in the Île-de-France, seem to have remained in circulation through to the early 7 th century. ${ }^{53}$

The second phase (587?-c.670) saw the creation of a coinage which lacks any reference to imperial authority and is hence considered "national", even though explicitly royal issues are rare. The largest group consists of tremisses with a place name on the obverse (some 1200 sites are known, often qualified with terms such as castellum, castrum, civitas, portus, vicus, and villa); the reverse features the name of a person followed by the title of monetarius (some 1600 are known), evidently the one responsible for the issue. A distinct subgroup consists of coins with names of ecclesiastical institutions (e.g., racio basilici sci martini) and some bishops. The weight of these tremisses (1.3 grams) is generally reduced as compared to the Roman standard (1.5 grams), and the alloy underwent various reductions. Some specimens struck at Marseille in the name of the emperor Mauritius Tiberius are of exceptional fineness ( 98 per cent), whereas a tremissis of Avitus, bishop of Clermont (674-689), has a gold content of roughly 10 per cent. ${ }^{54}$

\footnotetext{
$5^{2}$ Lafaurie and Pilet-Lemière, Monnaies du Haut Moyen-Âge, pp. 17-18.

53 Bompaire, "Du solidus d'or au denier d'argent", p. 108; and McCormick, "Coins and the economic history of post-Roman Gaul", pp. 337-54.

54 Blet-Lemarquand, Bompaire and Morrisson, "Platine et plomb dans les monnaies d'or mérovingiennes" p. 180; and Bompaire, "Du solidus d'or au denier d'argent" p. 116.
} 
The third phase began around $670-675$. With its introduction of the silver penny, this phase marks one of the most debated topics in the history of early medieval Europe. The name of this coin - the denarius - is known from its appearance on a handful of specimens, such as the pennies coined at Lyon with the legend lugduno dinarios; it therefore revived the name of the archetypal Roman silver coin, even though it did not share any metrological links with its classical inspiration. The chronology (imprecise though it is) is suggested by some pennies minted at Tours in the name of Childeric II (663-675) and others issued by the aforementioned Avitus, bishop of Clermont. ${ }^{55}$

Unlike what one might assume, the transition to silver does not seem to have entailed significant changes in the patterns of coin issues (at least not in the short term). The name of the king remained generally absent, but episcopal issues grew more common, and it is above all thanks to certain lists of bishops (especially for Paris) that we can determine a precise dating for some issues. ${ }^{56}$ The weight and dimensions remained roughly those of the tremisses (1.3 grams). The volume of coin issues not only did not increase, but in fact appears to have decreased. The corpus of single-finds within the boundaries of modern France is only just over 200 denarii, as compared to 780 tremisses from the preceding phase. In 1996, Jean Lafaurie estimated the total number of known specimens at ca. 3500, while underscoring that 2294 of these came from a single hoard (that of Nice-Cimiez, dép. Alpes-Maritimes, found in 1851). A further 780 hailed from the other seven known hoards containing Merovingian pennies in clusters ranging from 30 to 380 specimens. The Rodez (Aveyron) hoard provided an additional nine specimens. ${ }^{57}$

These are necessarily cautious estimates, given the difficulty in producing a census that takes into account private holdings and auction sales, but they at least provide us with relative orders of magnitude. The reduced number of known specimens is unquestionably striking, particularly if one considers the symbolic value that this monetary reform has taken on in early medieval historiography. It is also striking when set against the much more dramatic surge in issues in England and Frisia (especially given the lack of an earlier monetary

55 Bayless et al., Anglo-Saxon Graves and Grave Goods offers new hypotheses on the transition from gold to silver in England, positing a much earlier date for the transition than has previously been assumed - perhaps even earlier than (or at least contemporaneous with) the Merovingian transition from gold to silver. For a sceptical response to their arguments, see Marion Archibald's chapter in the same volume.

56 Lafaurie and Barrandon, "Monnaies épiscopales".

57 Geneviève and Sarah, "Le trésor de deniers mérovingiens de Rodez", p. 480 (with further references). 
tradition in the latter). ${ }^{58}$ Here, then, we can note the development of quite distinct pathways within a broadly shared framework, i.e., the replacement of gold with silver and the persistence of shared weights. (Note that the first pennies and sceattas conserved the weight of 1.3 grams, equivalent to $c$. 20 Troy grains, which had been the standard of the tremisses.)

Without entering into the details of these developments, it is worth signalling the insights that might come from a multidisciplinary approach towards the still-unresolved questions concerning the roles of public authorities and moneyers, the factors behind the extreme fragmentation of mint sites, the crisis of the fiscal system, and the possible role of Mediterranean commerce in the supplying of precious metal, notably gold.

Jean-Pierre Chambon's linguistic analysis of the Merovingian tremissis legends shed light on the public nature of the sites in which minting activity occurred, which in turn prompted a reconsideration of the decentralized structure of the Merovingian administration. Here taking up some hypotheses proposed by Jean Lafaurie, Chambon argued that the extreme fragmentation of the issuing sites (with some mints attested on a mere handful of specimens) was due not to the lack of control on the part of the public authority, but rather to the need to adapt to growing ruralization. ${ }^{59}$ Philip Grierson and Mark Blackburn, in contrast, argued that Merovingian coinage was "essentially non-royal in character".60

As for metallurgical analyses, these (coupled with a close study of the written evidence) have offered valuable insights into the rhythms of the decline in intrinsic value, the role of Byzantine gold in the supplying of the Merovingian mints, and the cause-and-effect relationship between the slowing of monetary circulation and the crisis of the fiscal system inherited from Rome. ${ }^{61}$

$5^{8}$ On sceattas, see Metcalf and Op den Velde, "The monetary economy of the Netherlands" and Abramson (ed.), Studies in Early Medieval Coinage. Even before the widespread use of metal detectors, it was already clear that sceattas were issued in far greater numbers than were Merovingian pennies. The differing regulatory regimes governing the use of metal detectors by amateurs and in archaeological research now make it difficult to compare finds from France with those from the United Kingdom and the Low Countries; see Naismith, "Kings, crisis," pp. 294-95. The same can be said for Italy, though it is worth adding that for both France and Italy (as well as other countries with similar laws governing the use of metal detectors), current techniques allow for a thorough recovery of coins in the context of archaeological excavations. As such, the ups and downs in monetary circulation that are evidenced in excavation reports can be considered reliable indicators of the trajectories of local circulation and the level of local monetization.

59 Chambon, "Lidentification des noms".

6o $M E C_{1}$, p. 9 o.

61 Blet-Lemarquand, Bompaire, and Morrisson, "Platine et plomb". 
Similarly interesting are the results of the analyses of the silver pennies. Notwithstanding the small sample size, the evolution of their intrinsic values offers innovative evidence for studying the rise of the Carolingian dynasty and the strengthening of royal power. The pennies coined from $75^{1}$ onward are distinguished from the earlier Merovingian issues by improved silver content and increasing uniformity within issues. Starting from the reign of Pepin the Short, the systematic mention of the king's name and the reduction in the number of mints provide further signs of the progressive centralization of monetary production under royal control. ${ }^{62}$

The modifications introduced under Pepin reflect a genuine reform effort, made clear by the increased dimensions of the coins (while keeping the same theoretical weight). Royal intervention in monetary issues was codified with the capitulary of Ver of $755,{ }^{63}$ the first legislation issued by a Frankish king concerning monetary matters. The capitulary defined the weight of the penny, declaring that from one pound of silver (i.e., 327.45 grams if one follows the weight traditionally attributed to the Roman pound; 322.22 if one accepts the position of Lucien Naville ${ }^{64}$ ), one could not mint more than 22 solidi worth of denarii. If we consider that one solidus (as a money of account) was made up of 12 pennies, the relationship between the pound and the penny was therefore $1 / 264(22 \times 12)$. Light pennies - such as those which had earlier been widely diffused in Provence, with a weight of ca. 1.14 grams, or 1/288 of a Roman pound - were therefore eliminated. Charlemagne in turn reinforced the penny, raising its weight to 1.7 grams as part of a general reform of weights and measures that also affected the pound (which was increased to $408 / 409$ grams) (Figure 4.7). The relationship of $1 / 240$ between the pound and the penny that had been established in the meantime remained unchanged. Charlemagne's reform left a trace in a clause of the Council of Frankfurt in May 794, with its mention of "new pennies [novi denarii] [which] bear our name [nominis nostri ... habent]." This brought to a close the process of normalization launched by Pepin. It introduced a definitive basis for a monometallic and single-denomination monetary system featuring a single coin (the penny), accompanied by two moneys of account: the solidus (equivalent to 12 pennies) and the pound (equivalent to 240 pennies). The Carolingian system can therefore be synthesized

\footnotetext{
62 Geneviève and Sarah, "Le trésor de deniers".

63 On the identification of the place where the capitulary was issued, see Bompaire and Dumas, Numismatique médiévale, p. 87.

64 Lafaurie, "Numismatique", pp. 126-28; MEC 1, p. 107-8; Portet, "Remarques sur les systhèmes métrologiques carolingiens"; and Naville, "Fragments de métrologie antique".
} 

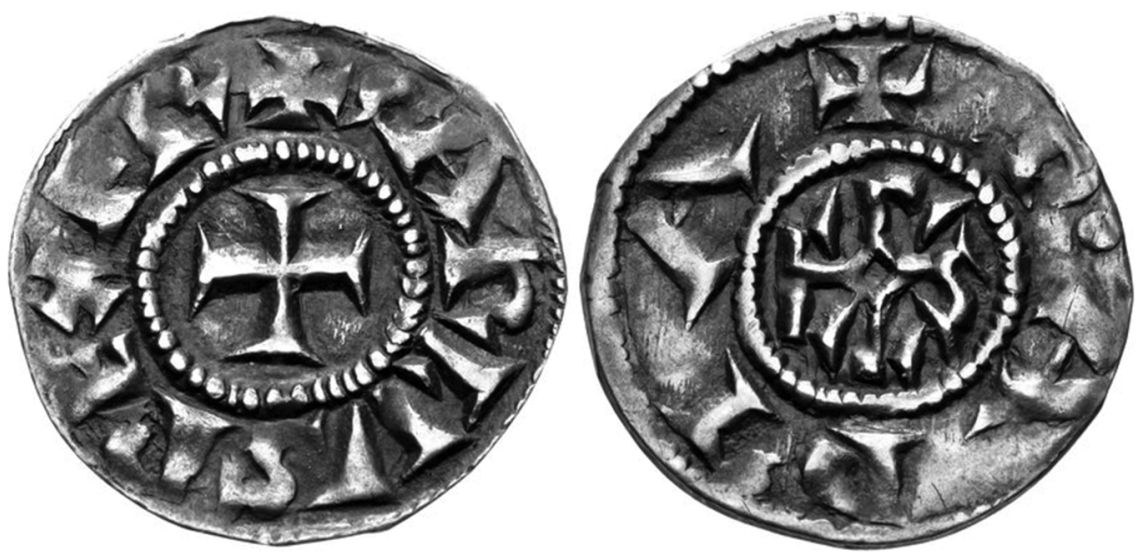

FIGURE 4.7 Silver denier/denarius of Charlemagne (768-814), Pavia mint. SOURCE: CNG.

according to the following framework: 1 pound (of account) $=20$ solidi (of account $)=240$ pennies $($ minted $)$; and 1 solidus $=12$ pennies .65

\section{The Uses of Coinage: Some Open Questions}

Thus far we have focused on predominantly technical themes, which are useful for describing coin production rather than patterns of actual use. Yet it is in the latter domain that recent scholarship has in fact made the most significant progress, while inevitably also raising new issues. It is also worth emphasizing - and this view is widely shared - that the study of early medieval Europe (including from a numismatic perspective) is among the topics that has benefitted most from the massive increase in archaeological evidence produced in recent decades. It has become possible to start to fill the void of "faits de masse" that Henri Pirenne identified as one of the most serious barriers to the reconstruction of pre-industrial economies. ${ }^{66}$ The growing use of metal detectors has also increased the volume of coin finds, though the differing European regulatory norms concerning the use of these tools have had significant consequences not only for the quantity of material legally brought to light, but also

65 Lafaurie, "Numismatique"; $M E C$ 1, pp. 206-9; and "Synodus Franconofurtensis", c. 5, ed. Boretius, p. 74 .

66 Grierson, "Problemi monetari dell'alto Medioevo", p. 67, citing Pirenne, Mahomet et Charlemagne, p. 219. 
from a qualitative perspective, given the greater attention given by detectorists to coins struck from precious metals.

Such consequences may be especially important for our period, which saw the transition from the late Roman trimetallic system to monometallic gold or silver systems. First, it becomes too easy to overlook, and therefore systematically underestimate, the final phases in the production and use of late bronze issues of uncertain authority and the prolonged circulation of properly imperial issues. Second, it becomes too easy to overestimate gold and silver issues which, precisely on account of their rarity, are sought after and examined with more care than the small late antique minimi or the billon pennies that were struck throughout Europe from the late 12th century onward. ${ }^{67}$

Mark Blackburn, who did much to support projects that would make it easier to analyse evidence of coin finds, was the first to draw attention to these concerns: "After 1180 coin finds in England become too plentiful and the currency was too uniform to make comprehensive recording of single-finds a practical proposition. For the later Middle Ages the study of coin circulation in England has to be based on samples from a limited number of sites".68 Even if the development of the Portable Antiquities Scheme makes it easier than previously to quantify and analyse the increased volume of coins in circulation in late medieval England, Blackburn's remark neatly captures the massive increase in monetary production starting in the 12th century, which stands in marked contrast to the early medieval panorama, and is more akin to levels under the Roman Empire. At the risk of being slightly provocative, it is worth recalling that according to some estimates, the two Gallic mints that were issuing coins for the usurper Tetricus in the 3rd century produced nearly a million coins a day. ${ }^{69}$ Pepin's coinage, by contrast, is known from 124 single-finds (as of 2014), ${ }^{70}$ and from specimens recovered from four hoards. ${ }^{71}$ One can only agree with Rory Naismith's call to go beyond merely acknowledging early medieval Europe's low level of monetization in order to explore those sectors in which coined money could in fact fulfil certain functions; ${ }^{72}$ and yet it is also crucial to stress the dramatic reduction in the scope of coin use.

On this front, one must keep in mind not only the tiny scale of issues, but also - and especially - the rigidity of the single-denomination systems that

67 See also above, n. $5^{8}$.

68 Blackburn, "Coin circulation in Germany during the early Middle Ages", p. 37, n. 1.

69 Burnett, Coinage in the Roman World, p. 123.

70 Coupland, "The use of coin in the Carolingian Empire in the ninth century", p. 273.

71 Naismith, "Kings, crisis", pp. 312-13.

72 Naismith, "Social significance"; Naismith, "Kings, crisis"; and Naismith, "Gold coinage and its use in the post-Roman West". 
emerged in the post-Roman West, whether gold or silver. Even the Carolingian system, although based on silver rather than gold, envisioned only the coining of the penny - a choice which, from a functional perspective, reflects a rather rudimentary system, poorly equipped to absorb fluctuations in the prices of everyday goods. Given the lack of fractional coinages (the minting of obols is attested in only a few mints within Francia), any price increase for goods valued at one penny could have been accommodated only by doubling the price to two pennies. How such a simplification of the earlier monetary system occurred, and how it must be interpreted, remain core questions in the study of early medieval economic history. Furthermore, the available evidence for the issuing of Merovingian pennies or of those Carolingian pennies which, in Italy, replaced Lombard tremisses ${ }^{73}$ indicates that the abandonment of gold in favour of silver did not always do much to increase the functionality of the monetary system and the level of monetization (save in the long run), ${ }^{74}$ even though silver was locally available. Moreover, it remains an open question which areas were supplying the silver; equally open to discussion is the role of silver hoarded by the Church and then melted down. ${ }^{75}$

The first step towards understanding the uses, as well as the limits, of the unidenominational systems of the early Middle Ages is to deepen our understanding of the factors that led to the definitive crisis of the trimetallic Roman system, and therefore to the disappearance of bronze and of silver fractions.

At the beginning of this chapter was mentioned the difficulty of reading and classifying many specimens, especially the late bronze issues, usually on account of their extremely poor quality. Yet their coarse appearance, due in some cases to the high proportion of lead they contain, must be carefully examined, rather than dismissed as simply the result of decreasing technical skill. Pursuing this phenomenon, we enter into much vaster historical problems, of both an economic and institutional nature. Already at the end of the 4th century and the beginning of the $5^{\text {th }}$, even some issues from the mint of Rome itself seemed to be characterized by a decline in quality that affected the legends (frequently irregular), the clarity of the types, and the alloy. This decline makes it difficult to distinguish official issues from imitations, but it also reveals two interesting features: on the one hand, a desire to reduce the costs of minting by adopting methods already observable in the mass production of other goods

\footnotetext{
73 Saccocci, "Rinvenimenti monetali nella Tuscia dell'Altomedioevo"; and Rovelli, "La moneta al tempo di Desiderio".

74 Hendy, The Economy, Fiscal Administration, no. viI, especially pp. 72-73.

$75 \quad M E C$ 1, p. 96; Op den Velde and Klaassen, Sceattas and Merovingian Deniers from Domburg and Westenschouwen, pp. 65-67; and Naismith, "Social significance", pp. 15-16.
} 
(such as lamps made using worn-out moulds); and on the other, an effort to satisfy the demand for petty coinage.

Thanks to the numerous archaeological excavations that have examined 6thcentury contexts from the Mediterranean region as well as near the Rhenish frontier, there is increasing awareness of the heterogeneous and sometimes quite substantial presence of bronze issues, both official and imitation, alongside mostly illegible blanks - a monetary landscape that until recently would have been entirely unexpected. ${ }^{76}$ Renewed attention has been paid to the phenomenon of the persistent circulation of late Roman issues, which in some cases were voluntarily broken into pieces in order to obtain the desired weight. ${ }^{77}$ And it is precisely from the (admittedly challenging) analysis of this material that it is becoming possible to examine anew the levels of monetary production and circulation in the crucial transition period between the $5^{\text {th }}$ and 6 th centuries.

Similarly interesting is the evidence concerning the production and use of the final series of late Roman - style silver fractions, not only in Ostrogothic, Lombard, and Byzantine Italy, but also in northern Gaul, between the Rhine and the Seine. These so-called argentei minuti weighed generally between 0.15 and 0.40 grams and had a diameter of less than $10 \mathrm{~mm}$. The extreme fragility of such light and tiny issues obviously threatens their survival in the ground as well as their visibility in the course of excavations, which likely explains why they have largely been recovered from funerary contexts.

These finds make tangible the references to argentei in Gregory of Tours. ${ }^{78}$ Like the bronze minimi of uncertain attribution and older Roman coins that remained in circulation, they point the way for future research. Until recently, the historiographical debate had focused on a different major theme: the abandonment of gold in favour of silver. At the end of this chapter, it seems worthwhile to highlight two outstanding questions of early medieval European economic and monetary history: first, the factors underpinning the creation of systems

76 In the Mediterranean context, especially unexpected is the Spanish example, first studied by Crusafont i Sabater, El sistema monetario visigodo, attributing certain bronze series to the Visigoths. These attributions remain disputed; see Marot, "La peninsula ibérica en los siglos V-VI”; Doménech Belda and Gutiérrez Lloret, "Viejas y nuevas monedas en la ciudad emiral de Madīnat Iyyuh"; Mora Serrano, "Old and new coins in southern Hispania in the 6th century AD". For Gaul and the Rhineland, see the broad synthesis in McCormick, "Coins and the economic history of post-Roman Gaul". For Italy, see Rovelli, "Contextes urbains".

77 Gricourt, Naumann, and Schaub, Le mobilier numismatique de l'agglomération secondaire de Bliesbruck; Chameroy and Guihard, Produktion und Recyceln; and Bompaire, Cardon, Geneviève and Marani, Les trouvailles de monnaies romaines en contexte médiéval.

78 The importance of Gregory of Tours (Liber in gloria confessorum, 110) in this regard has been noted by McCormick, "Coins and the economic history", p. 354. 
lacking both multiple and fractional currencies; and second, the economic implications of this phenomenon. As we have seen, the archaeological discoveries of recent decades have supplied evidence for the production and use of petty coinage, whether of bronze or silver, across a much wider chronological and geographical span that was previously believed. Through the careful examination of archaeological finds and attendant classification efforts, there is hope that future research will establish more precisely the chronological limits and economic spaces that defined the minting and use of such specimens.

\section{Acknowledgements}

I am very grateful to Rowan Dorin for translating this article into English.

\section{Bibliography}

\section{Primary Sources}

De rebus bellicis, ed. R. Ireland, Oxford, 1979.

Edictum Rothari, in Leges Langobardorum, ed. F. Bluhme (Monumenta Germaniae Historica: Leges, 4), Hanover, 1868.

Gregory of Tours, Liber in gloria confessorum, ed. B. Krusch (Monumenta Germaniae Historica: Scriptores rerum Merovingicarum, 1, 2), Hanover, 1885.

Procopius, History of the Wars, ed. H.B. Dewing, 5 vols., Cambridge, Mass., 1961-1962. "Synodus Franconofurtensis" (Council of Frankfurt), in Capitularia regum Francorum, ed. A. Boretius (Monumenta Germaniae Historica: Capitularia, 1), Hanover, 1883, $73-78$, no. 28 .

\section{Secondary Literature}

Abdy, R., "After Patching: imported and recycled coinage in fifth- and sixth-century Britain", in Cook and Williams, Coinage and History, 2006, 75-98.

Abramson, T. (ed.), Studies in Early Medieval Coinage, vol. 1: Two Decades of Discovery, Woodbridge, 2008.

Arslan, E.A., "Dalla classicità al Medioevo. La moneta degli Ostrogoti", Numismatica e Antichità classiche. Quaderni ticinesi 33 (2004), 429-62.

Arslan, E.A., "La monetazione di Ratchis, re dei Longobardi: dubbi e problemi", in Homenatge al dr. Leandre Villaronga/Acta Numismàtica 21-23 (1991-1993), 337-45.

Arslan, E.A., "Una riforma monetaria di Cuniperto, re dei Longobardi (688-70o)", Numismatica e Antichità classiche. Quaderni ticinesi 15 (1986), 249-75. 
Arslan, E.A., "Sequenze dei conii e valutazioni quantitative delle monetazioni argentea ed aurea di Benevento Longobarda”, in G. Depeyrot, T. Hackens, and G. Moucharte (eds.), Rythmes de la production monétaire, de l'Antiquité à nos jours, Louvain-laNeuve, 1987, 387-409.

Asolati, M., Praestantia nummorum. Temi e note di numismatica tardo antica e alto medievale, Padua, 2012.

Babelon, E., Traité des monnaies greques et romaines, Vol. 1, Théorie et pratique, Paris, 1901.

Banaji, J., Exploring the Economy of Late Antiquity: Selected Essays, Cambridge, 2016.

Baratte, F., "Les ateliers d'argenterie au Bas-Empire”, Journal des Savants (1975), 193-212.

Baratte, F., "Les objects précieux dans la vie économique et sociale du monde romain à la fin de l'Antiquité", Revue Numismatique 159 (2003), 205-16.

Bayliss, A., Hines, J., Nielsen, K.H., McCormac, G., and Scull, C., Anglo-Saxon Graves and Grave Goods of the 6th and 7 th Centuries AD: A Chronological Framework, London, 2013.

Blackburn, M.A.S., "Coin circulation in Germany during the early Middle Ages: The evidence of single-finds", in B. Kluge (ed.), Fernhandel und Geldwirtschaft, Sigmaringen, 1993, 37-54.

Blackburn, M.A.S., “'Productive' sites and the pattern of coin loss in England, 6oo-1180”, in T. Pestell and K. Ulmschneider (eds.), Markets in Early Medieval Europe: Trading and "Productive" Sites, 650-850, Macclesfield, 2003, 20-36.

Blet-Lemarquand, M., Bompaire, M., and Morrisson, C., "Platine et plomb dans les monnaies d'or mérovingiennes: nouvelles perspectives analytiques", Revue Numismatique 166 (2010), 175-98.

Bompaire, M., "Du solidus d'or au denier d'argent: genèse de la monnaie médiévale", in P. Contamine, M. Bompaire, S. Lebecq and J.-L. Sarrazin, L'Économie médiévale, Paris, 1993, 103-34.

Bompaire, M., Cardon, T., Geneviéve, V., and Marani, F. (eds.), Les trouvailles de monnaies romaines en contexte médiéval. Actes du colloque de Paris, 27-28 février 2015/ Journal of Archaeological Numismatics 5/6 (2015-2016).

Bompaire, M., and Dumas, F., Numismatique médiévale, Turnhout, 2000.

Bougard, F., "Le crédit dans l'Occident du haut Moyen Âge: documentation et pratique", in J.-P. Devroey, L. Feller and R. Le Jan (eds.), Les élites et la richesse au haut Moyen Âge, Turnhout, 2010, 439-77.

Brenot, C., "Du monnayage impérial au monnayage mérovingien: l'exemple d'Arles et de Marseille", in C. Lepelley (ed.), La fin de la cité antique et le début de la cité médiévale de la fin du IIIe siècle à l'avènement de Charlemagne, Bari, 1996, 147-6o.

Bruand, O., Voyageurs et marchandises aux temps carolingiens, Brussels, 2002.

Burnett, A., Coinage in the Roman World, London, 1987. 
Callegher, B., "Una moneta di re Arioaldo (624-636) dall'area ex-carceri di Oderzo (OPITERGIUM): alcune note", Forum Iulii 33 (2009), 213-24.

Callegher, B., "Tra Bizantini e Longobardi in Friuli: problemi di emissione e circolazione monetaria", in Paolo Diacono e il Friuli altomedievale (secc. VI-X). Atti del XIV Congresso internazionale di studi sull'Alto Medioevo, vol. 2, Spoleto, 2001, 671-96.

Carrié, J.-M., "Les échanges commerciaux et l'État antique tardif", in J. Andreau et al., Les échanges dans l'Antiquité: le rôle de l'état, Saint-Bertrand-de-Comminges, 1994, 175-211.

Carrié, J.-M., "Were late Roman and Byzantine economies market economies? A comparative look at historiography", in C. Morrisson (ed.), Trade and Markets in Byzantium, Washington D.C., 2012, 13-26.

Castro Priego, M., "Absent coinage: archaeological contexts and tremisses on the central Iberian peninsula in the 7 th and 8th Centuries AD", Medieval Archaeology 6o-61 (2016), 27-56.

Chambon, J.-P., "L’identification des noms d'ateliers monétaires mérovingiens (Arvernie et entours): point de vue de linguiste", Revue Numismatique 157 (2001), $347-405$.

Chameroy, J., and Guihard, P.M. (eds.), Produktion und Recyceln von Münzen in der Spätantike. Produire et recycler la monnaie au bas-empire, Mainz, 2016.

Cook, B., and Williams, G. (eds.), Coinage and History in the North Sea World, c.AD 50o1250: Essays in Honour of Marion Archibald, Leiden, 2006.

Coupland, S., "The use of coin in the Carolingian Empire in the ninth century", in R. Naismith, M. Allen, and E. Screen (eds.), Early Medieval Monetary History: Studies in Memory of Mark Blackburn, Farnham, 2014, 257-93.

Crawford, M., "Money and exchange in the Roman world", Journal of Roman Studies 6o (1970), 40-48.

Crusafont i Sabater, M., El sistema monetario visigodo: cobre y oro, Barcelona, 1994.

Curta, F., "Merovingian and Carolingian gift giving", Speculum 81 (2006), 671-99.

Davies, W., and Fouracre, P. (eds.), The Languages of Gift in the Early Middle Ages, Cambridge, 2010.

Delmaire, R., Largesses sacrées et res privata. L'aerarium impérial et son administration du IVe au VIe siècle, Rome, 1989.

Delogu, P., Le origini del Medioevo, Rome, 2010.

Delogu, P., "Reading Pirenne again", in R. Hodges and W. Bowden (eds.), The Sixth Century: Production, Distribution and Demand, Leiden, 1998, 15-40.

Devroey, J.-P., Économie rurale et société dans l'Europe franque (VIe-IXe siècles), vol. 1: Fondements matériels, échanges et lien social, Paris, 2003.

Doménech Belda, C., "Moneda y espacios de poder en el reino visigodo. Los tremises de El Tomo de Minateda (Hellín, Albacete)", Arqueología y Territorio Medieval 21 (2014), 9-37. 
Doménech Belda, C., and Gutiérrez Lloret, S., "Viejas y nuevas monedas en la ciudad emiral de Madīnat Iyyuh (El Tolmo de Minateda, Hellín, Albacete)”, Al-Qantara 27 (2006), 337-74.

Feller, L., Gramain, A., and Weber, F., La fortune de Karol. Marché de la terre et liens personnels dans les Abruzzes au haut Moyen Âge, Rome, 2005.

Feller, L., and Rodriguez, A. (eds.), Objets sous contrainte. Circulation des richesses et valeur des choses au Moyen Âge, Paris, 2013.

Gelichi, S., and Hodges, R. (eds.), From One Sea to Another: Trading Places in the European and Mediterranean Early Middle Ages/Da un mare all'altro. Luoghi di scambio nell'alto Medioevo europeo e mediterraneo, Turnhout, 2012.

Geneviève, V., and Sarah, G., "Le trésor de deniers mérovingiens de Rodez (Aveyron). Circulation et diffusion des monnayages d'argent dans le Sud de la France au milieu du VIIIe siècle", Revue Numismatique 166 (2010), 477-507.

Gricourt, D., Naumann, J., and Schaub, J., Le mobilier numismatique de l'agglomération secondaire de Bliesbruck (Moselle), fouilles 1978-1998, Paris, 2009.

Grierson, P., "Commerce in the Dark Ages: a critique of the evidence", Transactions of the Royal Historical Society, 5th ser., 9 (1959), 123-4O; repr. in P. Grierson, Dark Age Numismatics, no. 2, London, 1979.

Grierson, P., "Problemi monetari dell'alto Medioevo", Bollettino della Società pavese di Storia patria 54 (1954), 67-82; repr. in P. Grierson, Dark Age Numismatics, no. 1, London, 1979 .

Grierson, P., and Blackburn, M., Medieval European Coinage, with a Catalogue of the Coins in the Fitzwilliam Museum, Cambridge. Vol. 1: The Early Middle Ages (5th-1oth Centuries), Cambridge, 1986.

Grierson, P., and Mays, M., Catalogue of Late Roman Coins in the Dumbarton Oaks Collection and in the Whittemore Collection: From Arcadius and Honorius to the Accession of Anastasius, Washington, D.C., 1992.

Hahn, W., with M.A. Metlich, Money of the Incipient Byzantine Empire (Anastasius I Justinian I, 491-565), Vienna, 2000.

Halsall, G., Barbarian Migration and the Roman West, 376-568, Cambridge, 2007.

Hendy, M., "East and west: divergent models of coinage and its use", in Il secolo di ferro: mito e realtà del $X$ secol. Settimane di studio del Centro italiano di studi sull'alto medioevo, 38, Spoleto, 1991, 637-74.

Hendy, M., The Economy, Fiscal Administration and Coinage of Byzantium (Collected studies series, $\mathrm{CS}_{305}$ ), Northampton, 1989.

Hendy, M., Studies in the Byzantine Monetary Economy, c.30o-1450, Cambridge, 1985. Hohlfelder, R.L., "A sixth-century hoard from Kenchreai", Hesperia 42 (1973), 89-101.

Howgego, C.J., "Why did ancient states strike coins?", Numismatic Chronicle 150 (1990), 1-25. 
Hunter, F., and Painter, K., Late Roman Silver: The Traprain Treasure in Context, Edinburgh, 2013 .

Johns, C., The Hoxne Late Roman Treasure: Gold Jewellery and Silver Plate, London, 2010. Kajava, M. (ed.), Gunnar Mickwitz nella storiografia europea tra le due guerre, Rome, 2007.

Kent, J.P.C., The Roman Imperial Coinage, Vol. 10: The Divided Empire and the Fall of the Western Parts $A D$ 395-491, London, 1994.

Lafaurie, J., "Numismatique. Des Carolingiens aux Capétiens", Cahiers de civilisation médiévale 13 (1970), 117-37.

Lafaurie, J., and Barrandon, J.N., "Monnaies épiscopales de Paris à l'époque mérovingienne", Cahiers de la Rotonde 20 (1998), 61-99.

Lafaurie, J., and Pilet-Lemière, J., Monnaies du haut Moyen Âge découvertes en France (Ve-VIIIe siècle), Paris, 2003.

Laiou, A.E., "Economic and Noneconomic Exchange", in A.E. Laiou (ed.)., The Economic History of Byzantium: From the Seventh through the Fifteenth Century, 3 vols., Washington, D.C., 2002, vol. 2, 681-96.

Le Jan, R., La société du haut Moyen Âge, Paris, 2003.

Magnus, B., Roman Gold and the Development of the Early Germanic Kingdoms: Aspects of Technical, Socio-Political, Artistic and Intellectual Development A.D. 1-550, Stockholm, 2001.

Marot, T., "La peninsula ibérica en los siglos V-VI: consideraciones sobre provisión circulation y usos monetarios", Pyrenae 31-32 (2000-2001), 133-6o.

Martín Viso, I., "Circuits of power in a fragmented space: gold coinage in the Meseta del Duero (sixth-seventh centuries)", in J. Escalona and A. Reynolds (eds.), Scale and Scale Change in the Early Middle Ages, Turnhout 2011, 215-52.

Mathisen, R.W., and Shanzer, D. (eds.), Romans, Barbarians and the Transformation of the Roman World, Aldershot, 2011.

McCormick, M., "Coins and the economic history of post-Roman Gaul: testing the standard model in the Moselle, ca 400-750", in J. Jarnut and J. Strothmann (eds.), Die Merowingischen Monetarmünzen als Quelle zum Verständnis des 7.Jahrhunderts in Gallien, Paderborn, 2013, 337-76.

McCormick, M., Origins of the European Economy: Communication and Commerce A.D. 300-900, Cambridge, 2001.

Metcalf, M., and Op den Velde, W., "The monetary economy of the Netherlands, c.69oc.76o and the trade with England: a study of the 'Porcupine' sceattas Series E", Jaarboek voor Munt- en Penningkunde 96 (2009), 1-284; 97 (2010), 285-506.

Metlich, M.A., The Coinage of Ostrogothic Italy (and a Die Study of Theodahad Folles by E.A. Arslan and M.A. Metlich), London, 2004.

Moneta e scambi nell'alto Medioevo (Settimane di studio del Centro italiano di studi sull'alto Medioevo, 8), Spoleto, 1961. 
Mora Serrano, B., "Old and new coins in southern Hispania in the 6th century AD", in Chameroy and Guihard, Produktion und Recyceln, 139-53.

Morrisson, C., "L'atelier de Carthage et la diffusion de la monnaie frappèe dans l'Afrique vandale et byzantine (439-695)", Antiquité Tardive 11 (2003), 65-84.

Morrisson, C., Byzance et sa monnaie, Paris, 2015.

Morrisson, C., "Emporia, money and exchanges: some reflections", in Gelichi and Hodges, From One Sea to Another, 467-76.

Morrisson, C., "Histoire monétaire et numismatique", in E. Menestò (ed.), Omaggio al Medioevo. I primi cinquanta anni del Centro italiano di studi sull'alto medioevo di Spoleto, Spoleto, 2004, 281-301.

Morrisson, C., "La monnaie byzantine hors de l'Empire: dons politiques et échanges économique", in Le relazioni internazionali nell'alto Medioevo (Settimane di studio della Fondazione Centro italiano di studi sull'alto Medioevo, 58), Spoleto, 2011, 27397 .

Morrisson, C., "Nummi byzantins et barbares du VIe siècle", in Charaktèr. Aphierôma stè Mando Oikonomidou, Athens, 187-93.

Morrisson, C., "Le zecche nell'Italia bizantina: un quadro d'insieme”, in L. Travaini (ed.), Le zecche italiane fino all'Unità, Rome, 2011, 415-25.

Naismith, R., "Gold coinage and its use in the post-Roman West", Speculum 89 (2014), $273-306$.

Naismith, R., "Kings, crisis and coinage reforms in the mid-eighth century", Early Medieval Europe 20 (2012), 291-332.

Naismith, R., Medieval European Coinage, with a Catalogue of the Coins in the Fitzwilliam Museum, Cambridge, Vol. 8: Britain and Ireland c.400-1066, Cambridge, 2017.

Naismith, R., "The social significance of monetization in the early Middle Ages", Past \& Present 223 (2014), 3-39.

Naville, L., "Fragments de métrologie antique", Revue suisse de Numismatique 22 (1920), 42-6o.

Naylor, J. "Coinage, trade and the origins of the English emporia, c. AD 650-750", in Gelichi and Hodges, From One Sea to Another, 237-66.

Op den Velde, W., and Klaassen, C.J.F., Sceattas and Merovingian deniers from Domburg and Westenschouwen, Middelburg, 2004.

Pirenne, H., Mahomet et Charlemagne, Brussels, 1937.

Pohl, W., and Mehofer, M. (eds.), Archaeology of Identity/Archäologie der Identität, Vienna, 2010.

Portet, P., "Remarques sur les systhèmes métrologiques carolingiens", Le Moyen Âge 97 (1991), 5-24.

Reden, S. von, "Money in the ancient economy: A survey of recent research", Clio 84 (2012) 141-74.

Rovelli, A., Coinage and Coin Use in Medieval Italy, Farnham, 2012. 
Rovelli, A., "Contextes urbains vs ruraux: L'Italie centro-septentrionale durant le haut Moyen Âge", Revue belge de Numismatique 161 (2015), 145-76.

Rovelli, A., "En marge de quelques émissions d'Odoacre et de Baduila. Variantes et activité monétaire en Italie entre le Ve et le Vie siècle", Bulletin de la Société française de Numismatique 69 (2014), 37-45.

Rovelli, A., "Gold, silver and bronze: an analysis of monetary circulation along the Italian coasts", in Gelichi and Hodges, From One Sea to Another, 267-95.

Rovelli, A., "La moneta al tempo di Desiderio", in G. Archetti (ed.), Desiderio. Il progetto politico dell'ultimo re longobardo, Spoleto, 2015, 479-92.

Rovelli, A., "Le monete. Aspetti della circolazione monetaria alla luce dei contesti della Basilica Hilariana", in P. Palazzo and C. Pavolini (eds.), Gli dèi propizi. La Basilica Hilariana nel contesto dello scavo dell'Ospedale Militare Celio (1987-200o), Rome, 2013, 209-10.

Saccocci, A., "Rinvenimenti monetali nella Tuscia dell'Altomedioevo: i flussi (secc. VI-X)", in C. Alberti and M. Baldassarri (eds.), Monete antiche. Usi e flussi monetari in Valdera e nella Toscana nord-occidentale dall'età romana al medioevo, Bientina, 2013, 21-34.

Sénac, P., and Gasc, S. (eds.), Monnaies du haut Moyen Âge. Histoire et archéologie (péninsule Ibérique-Maghreb, VIIe-XIe siècle), Toulouse, 2015.

Skre, D., "Markets, towns and currencies in Scandinavia ca AD 200-1000", in Gelichi and Hodges, From One Sea to Another, 47-63.

Skre, D. (ed.), Means of Exchange: Dealing with Silver in the Viking Age, Aarhus, 2008.

Spufford, P., Money and its Use in Medieval Europe, Cambridge, 1988.

Vera, D., "Dalla liturgia al contratto: Cassiodoro Variae, X, 28 e il tramonto della città curiale", in P.C. Díaz and I.M. Viso (eds.), Between Taxation and Rent: Fiscal Problems from Late Antiquity to Early Middle Ages/Entre el Impuesto y la Renta. Problemas de la fiscalidad tardoantigua y altomedieval, Bari, 2011, 51-70.

Vera, D., "Stato, fisco e mercato nell'Italia gotica secondo le Variae di Cassiodoro: fra ideologia politica e realtà", in L. Capdetrey and C. Hasenohr (eds.), Agoranomes et édiles. Insitutions des marchés antiques, Paris, 2012, 245-58.

Werner, J., Münzdatierte Austrasische Grabfunde, Berlin, 1935.

Wickham, C., Framing the Early Middle Ages: Europe and the Mediterranean, 400-80o, Oxford, 2005 .

Wickham, C., "The other transition: from the ancient world to feudalism", Past \& Present 103 (1984), 3-36.

Williams, G., "The circulation and function of coinage in conversion-period England, $c$. AD 580-675", in Cook and Williams, Coinage and History, 145-92. 